\title{
Characteristics of regenerated keratin and keratin-based film
}

\author{
V. V. Havryliak ${ }^{1}$, V. V. Mykhaliuk ${ }^{2}$, V. V. Kochubei ${ }^{1}$ \\ ${ }^{1}$ Lviv Polytechnic National University \\ 12, S. Bandery Str., Lviv, Ukraine, 79013 \\ 2 Institute of Animal Biology, NAAS of Ukraine \\ 38, Stusa Str., Lviv, Ukraine, 79034 \\ vitahavryliak@gmail.com
}

\begin{abstract}
Aim. Determination of the characteristics of regenerated keratin obtained from human hair, development of keratin-based films, and studing their surface morphology and adsorption capacity. Methods. Keratins were extracted by sulfitolysis. The structure of regenerated keratin was studied by IR spectroscopy, thermogravimetry, and electrophoresis. Keratin-based films were made by casting. Their biocompatibility was analyzed in the adsorption test by incubation in human serum. Scanning electron microscopy was used to evaluate the surface morphology of the films. Results. The regenerated keratin is represented mainly by proteins of intermediate filaments and is characterized by better thermal properties than the native one. The keratinbased films had a pronounced relief structure. The adsorption test shows the ability of the films to adsorb albumin from human serum on their surface. Conclusions. The mild extraction of keratins by sulfitolysis ensures the preservation of their native properties and the ability of keratin-based films to form bonds with blood proteins.
\end{abstract}

Ke y w or d s: biopolymers, keratin, sulfitolysis, thermogravimetric analysis, films, adsorption.

\section{Introduction}

One of the most important innovative approaches in various fields for the development of sensors, the creation of optoelectronic materials, robotics, and biomedicine is the design of new materials. Special attention is now paid to the development of materials based on natural biopolymers. Fibroin, elastin, chitosan, keratin are widely used in cell engineering and regenerative medicine due to their wide avai- lability, low toxicity, biocompatibility, and bioactivity [1-2].

One of the most promising biopolymers is keratin, which is characterized by a complex hierarchical structure of subunits - from $\alpha$-chains through microfibrils to fiber (Fig. 1). At the molecular level, keratins differ from other structural proteins by a high level of disulfide bonds, which ensure the formation of

(C) 2021 V. V. Havryliak et al.; Published by the Institute of Molecular Biology and Genetics, NAS of Ukraine on behalf of Biopolymers and Cell. This is an Open Access article distributed under the terms of the Creative Commons Attribution License (http://creativecommons.org/licenses/by/4.0/), which permits unrestricted reuse, distribution, and reproduction in any medium, provided the original work is properly cited 
a compact three-dimensional structure that is resistant to biological and chemical degradation [3].

It is known that the structure of keratin is similar to the extracellular matrix of biological tissues, due to which the biomaterials based on it are widely used as matrices for cell adhesion and as a basis for a cellular support of native tissues [5].

A unique characteristic of extracted keratins is their ability to self-assembly and selfaggregation [6]. There is enough information in the scientific literature on the use of keratin for the development of nanofibers [7], hydrogels [8], films [9], 3D scaffolds for tissue engineering [10], nanocontainers for controlled drug delivery [11], biomaterials for wound healing [12], regeneration of nerve fibers [13], heavy metal binding [14]. There are many different methods for extracting keratin, but all of them are mainly based on the oxidation or reduction of disulfide bonds in its molecules [15]. The materials based on regenerated keratins can differ significantly in composition, structure, and properties, depending on the specific source and methods of their extraction [16].

The purpose of our work was to investigate the biochemical characteristics of solubilized keratins obtained from human hair by sulfitolysis, to develop films on their basis, and to determine their main characteristics.

\section{Materials and Methods}

\section{Obtaining regenerated keratin}

The hair samples were obtained from volunteers. This study was conducted according to the international bioethical norms, legislative documents of Ukraine, and protocol approved by the Committee for Bioethics of the Institute of Animal Biology of the National Academy
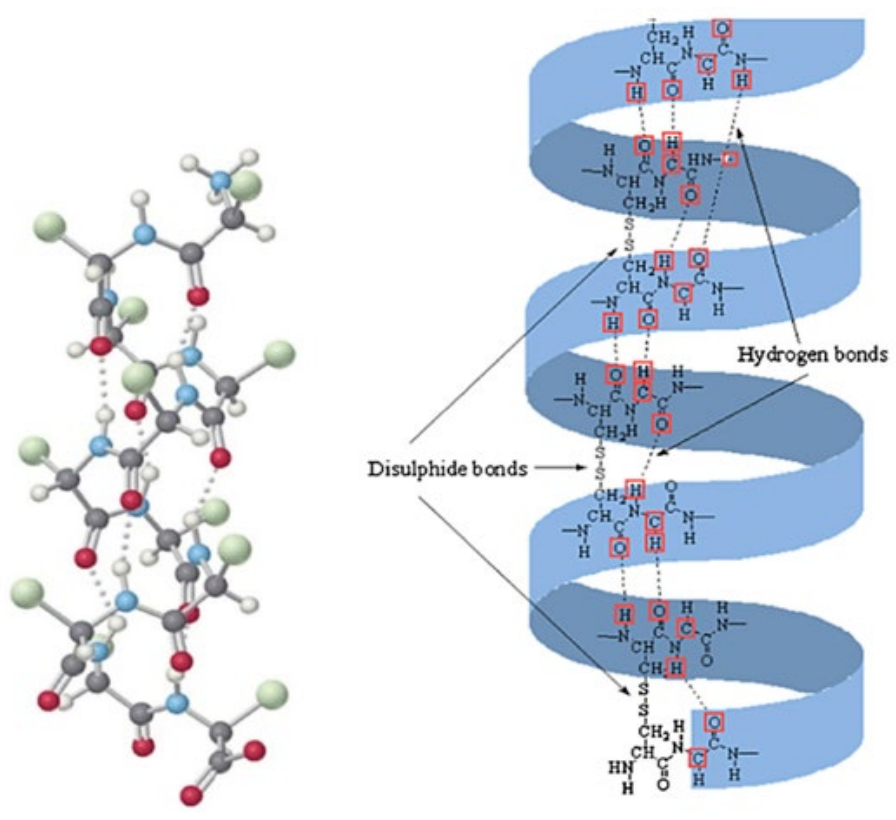

Fig. 1. The a-helical structure of keratin [4] 
of Agrarian Sciences of Ukraine (№91, 05.08.2020).

For the extraction of keratin, the method of sulfitolysis was used. Sulfitolysis is the reversible process of keratin extraction where sodium metabisulfite $\left(\mathrm{Na}_{2} \mathrm{~S}_{2} \mathrm{O}_{5}\right)$ is used as a reducing agent. As a result of sulfitolysis, S-sulfonate residue ( $\mathrm{R}-\mathrm{S}_{-} \mathrm{SO}_{3}{ }^{-}$), and cysteine thiol (R-S-) are produced. The sulfitolysis reaction is shown schematically in this formula: $\mathrm{R}-\mathrm{S}-\mathrm{S}-\mathrm{R}+$ $\mathrm{Na}_{2} \mathrm{SO}_{3} \leftrightarrow \mathrm{R}-\mathrm{S}^{-}+\mathrm{R}-\mathrm{S}-\mathrm{SO}_{3}^{-}$[17].

This method involves the use of $8 \mathrm{M}$ urea, $0.1 \mathrm{M}$ sodium dodecyl sulphate (SDS), and $0.5 \mathrm{M}$ sodium metabisulfite ( $\mathrm{m}$-BS) in the composition of the extraction mixture [18].

In order to separate the keratin solution from the extraction mixture, the solution resulting from extraction was filtered and dialyzed for 3 days against deionized water using dialysis cassettes for the low molecular weight proteins and centrifuged at $12000 \mathrm{~g}$ for $20 \mathrm{~min}$.

The protein content in the supernatant was determined by the colorimetric method, using the Bradford reagent [19]. $1 \mathrm{ml}$ of Bradford reagent and $1 \mathrm{ml}$ of the obtained protein extract were mixed, the mixture was then incubated for 30 minutes at room temperature and the absorbance was measured at a wavelength of $595 \mathrm{~nm}$. To determine the concentration of keratin, a calibration curve was built, using the standard solutions of serum albumin (Sigma).

Protein electrophoresis was performed in $12.5 \%$ polyacrylamide gel under denaturation conditions with SDS in the Laemmli buffer system [20]. After the electrophoretic separation, the gels were stained with the solution of $0.2 \%$ Coomassie R-250 for 1 hour. The dye was washed with the solution of $7 \%$ acetic acid in distilled water.
The protein solution was lyophilized and used as a regenerated keratin for the research.

\section{Thermal analysis of the regenerated keratin}

The complex thermal analysis of keratin was carried out on a derivatograph Q-1500 of the Paulik-Paulik-Erdey system connected to a personal computer. The studies were performed in the temperature range of $20-400{ }^{\circ} \mathrm{C}$, in the air atmosphere. The heating rate of the samples was $3{ }^{\circ} \mathrm{C}$ per minute. The thermal behavior of the native keratin was compared with that of the regenerated one. Aluminium oxide served as the reference substance.

In the given thermograms, the thermogravimetric curves (TG) reflect the weight loss of the samples during heating. The differential thermogravimetric curves (DTG) correspond to the rate of the weight loss of the samples and are the result of the differentiation of the TG curves. The differential thermal analysis (DTA) curves illustrate the thermal effects of the processes.

\section{IR spectroscopy of regenerated keratin}

Lyophilized keratin was compressed into tablets with potassium bromide. IR spectra were recorded using a SPECORD $80 \mathrm{M}$ spectroscope, which automatically detects IR transmission spectra in the wavelength range of 4000 to $400 \mathrm{~cm}^{-1}$.

\section{Preparing the films}

$5 \mathrm{ml}$ of $4 \%$ solution of keratin were prepared in distilled water from the regenerated keratin adding $1 \mathrm{ml}$ of $1 \%$ aqueous solution of glycerol as a plasticizer. The resulting proteinglycerol mixture was poured in a thin layer 
with a thickness of no more than $3.0 \mathrm{~mm}$ into Petri dishes for cultivating cells, which were then placed in a thermostat for $24 \mathrm{~h}$ at a temperature of $37^{\circ} \mathrm{C}$. After that, they were fixed with water vapour in a desiccator with a ground lid for $24 \mathrm{~h}$. Water vapour fixation is one of the safest methods for stabilizing and shaping polymer biofilms. It is particularly important in producing biofilms for implantation in a living organism. Besides, such a method of fixation is easy to perform. The water vapour formed in the desiccator is then accumulated by hydrophilic glycerol, which leads to the film's swelling, thus making it more flexible $[21,22]$.

\section{Scanning microscopy of the film surface}

The surface features of the films were studied using a REMMA-102 scanning electron microscope. Scanning the sample surface was carried out using an electron beam with a diameter of a few nanometers and electron energy of $0.2-40 \mathrm{kV}$.

\section{The study of the biocompatibility of the films based on regenerated keratin}

The adsorption properties of the films were studied by electrophoresis in $12.5 \%$ PAGE. The film fragments of approximately $0.6 \times 0.6 \mathrm{~cm}^{2}$ were cut out, placed in a special plate, and incubated with human blood serum for $5 \mathrm{~min}$ and $15 \mathrm{~min}$ in a thermostat at $37^{\circ} \mathrm{C}$. After the incubation, the serum was collected in signed test tubes and used for electrophoresis as a contact serum.

After serum collection, all film fragments were washed in distilled water and placed on a new plate. These fragments were incubated in SDS for 5 min and $15 \mathrm{~min}$ in a thermostat at $37{ }^{\circ} \mathrm{C}$. After incubation, the SDS solution was collected in specially signed test tubes and used for electrophoresis as a desorbed protein solution. The contact serum was used to assess the binding of serum proteins to the keratin films, while the desorbed protein solution made it possible to estimate residual proteins on the keratin film from their initial amount in the contact serum [23].

\section{Results and Discussion}

The first stage of this work was to obtain regenerated keratin and to study its characteristics. Figure 2 shows an electrophoregram of keratin obtained from human hair by sulfitolysis. As a result of electrophoretic analysis, two polypeptide chains with the molecular weights in the range of $40-65 \mathrm{kDa}$ were identified. According to the available literature data, the proteins with such molecular weights belong to the proteins of intermediate filaments (IF) of types I - acidic and II - basic [5]. Intermediate filaments proteins are composed of 8 subunits of polypeptides that differ from each other in their molecular weight and electric charge. These polypeptides are found in all keratins, but the ratio of their components may vary. They are characterized by low sulphur content, have an alpha-helix conformation, are localized in the fiber cortex, and are responsible for its strength [24].

In this case, the low molecular weight keratin-associated proteins were not found. It is obvious that the method of sulfitolysis provides the predominant extraction of fibrillar proteins, which are often used in various areas of biomedicine due to their ability to the selforganisation in complex structures. 


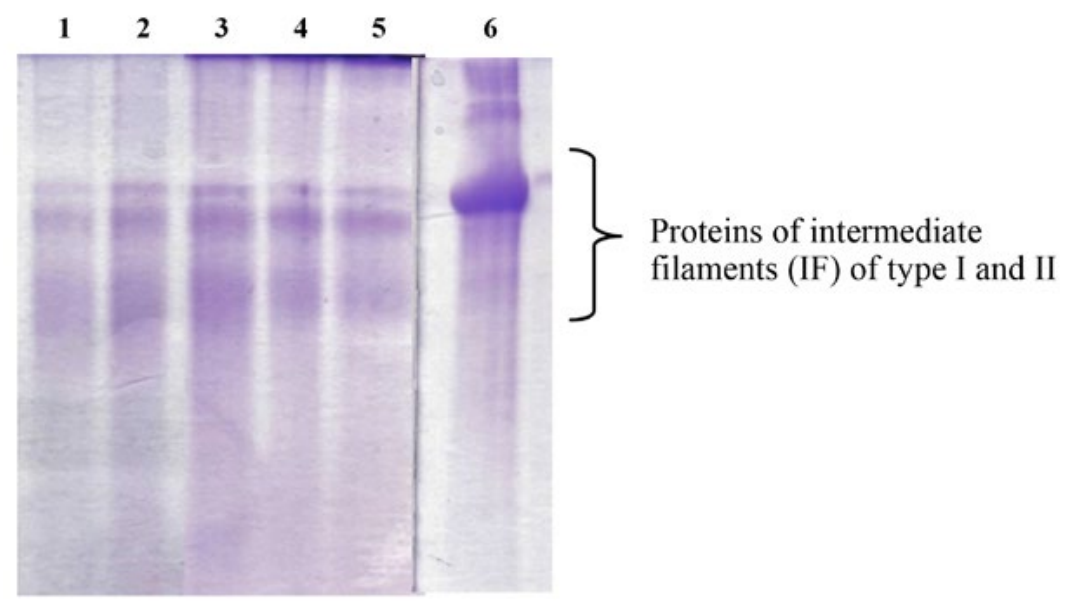

Fig. 2. Polyacrylamide gel electrophoresis of regenerated keratin (1-5 - keratin extract obtained from human hair, molecular weight 40-65 kDa, 6 - serum albumin, molecular weight $69 \mathrm{kDa}$ )

Figure 3 shows the IR spectrum of the lyophilized keratin extract, which contains valence vibrations bands of amide groups of proteins of intermediate filaments of type I (1640-1660 $\mathrm{cm}^{-1}$ ) and type II (1520$\left.1550 \mathrm{~cm}^{-1}\right)$.

For the analysis of protein structure, the most interesting are the three bands in the infrared range of wavelengths, which correspond to the vibrations of the appropriate bonds pre- sent in the peptide chain. These include the bands produced by valence vibrations of the $\mathrm{N}-\mathrm{H}\left(3300 \mathrm{~cm}^{-1}\right)$ and $\mathrm{C}=\mathrm{O}\left(1640-1660 \mathrm{~cm}^{-1}\right)$ bonds present in IF of type I, and the band associated with the deformation vibrations of NH bonds (1520-1550 $\left.\mathrm{cm}^{-1}\right)$ present in IF of type II [25].

During the formation of the secondary structure of the protein, the energies of these three vibrations change. As a result, the shifts

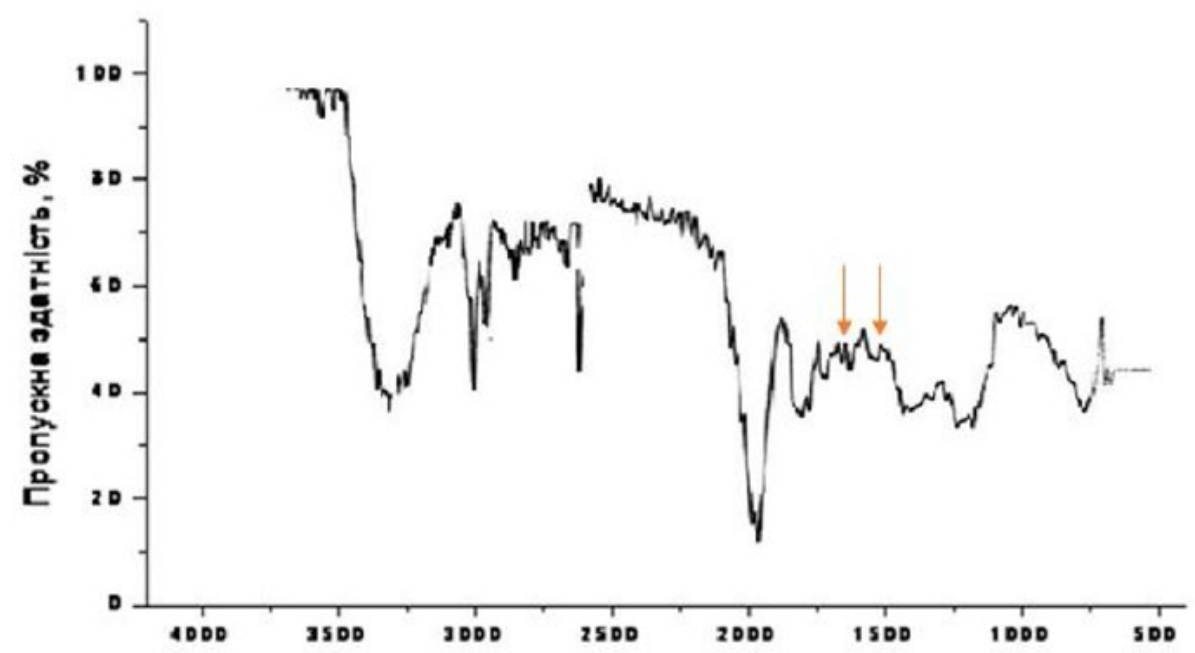

Fig. 3. IR spectrum of the regenerated keratin 
of the vibration bands to the region of the resistance frequencies are recorded.

The first two bands, corresponding to the valence vibrations of $\mathrm{N}-\mathrm{H}$ and $\mathrm{C}=\mathrm{O}$ bonds, are shifted to the region of lower frequencies. This is due to the fact that the formation of a hydrogen bond leads to the weakening of bonds in the amide and carbonyl groups because of the displacement of the nitrogen atom of the amide group and the oxygen atom of the carbonyl group towards the acceptor or proton donor, respectively.

The band of deformation vibrations of the $\mathrm{N}-\mathrm{H}$ bond, which is present in IF of type II, is shifted towards high frequencies. This is due to the fact that the hydrogen bond prevents the deformation of the $\mathrm{N}-\mathrm{H}$ bond in the amide group.

This indicates that the applied soft extraction methods allowed the obtaining of reduced keratin, which for its characteristics corresponds to the native keratin of human hair.

The thermal stability of native and regenerated keratin was investigated using a complex thermal analysis, the results of which are presented in Fig. 4.

$\boldsymbol{A}$

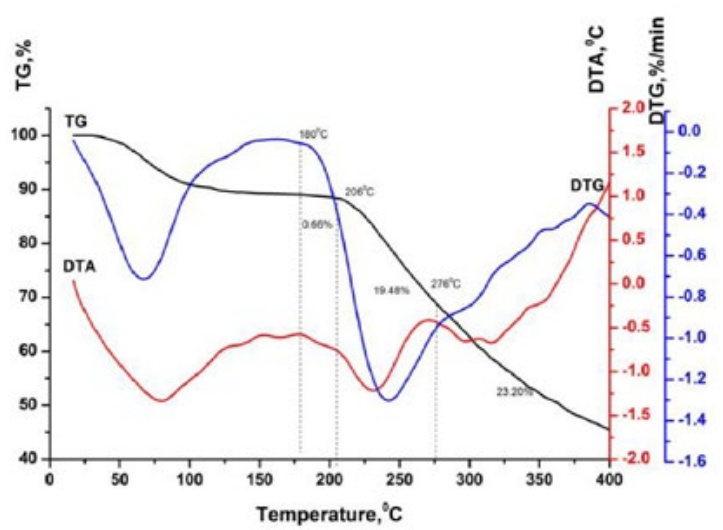

The weight loss (10.96\%) of native keratin in the temperature range of $20-180{ }^{\circ} \mathrm{C}$ corresponds to the processes of keratin dehydration [26]. This process is accompanied by the appearance of an endothermic effect on the DTA curve and a clear extremum on the DTG curve. A slight weight loss $(0.66 \%)$ of native keratin in the temperature range of $180-206{ }^{\circ} \mathrm{C}$ can be explained by initial destructive processes in the keratin molecule. A shallow endothermic effect accompanies the weight loss of keratin on the DTA curve.

The intense weight loss of the native keratin sample in the temperature range of 206$276{ }^{\circ} \mathrm{C}(19.48 \%)$ corresponds to the simultaneous processes of thermal denaturation of a-helices of intermediate filaments of native keratin and pyrolysis of the matrix [27]. This process is accompanied by a clear endothermic effect on the DTA curve and a deep extremum on the DTG curve.

In the temperature range of $276-400{ }^{\circ} \mathrm{C}$, deep destructive and thermo-oxidative processes take place in native keratin, which end with the combustion of destruction residues. An endothermic effect appears on the DTA curve in

$\boldsymbol{B}$

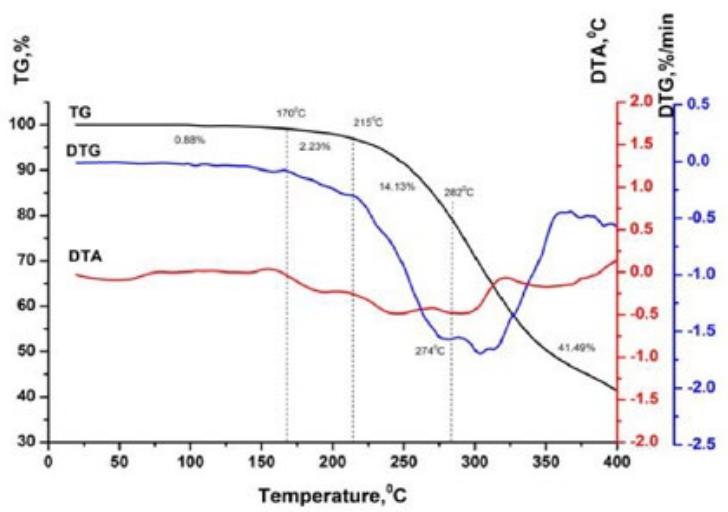

Fig. 4. Thermogram of native $(\boldsymbol{A})$ and regenerated $(\boldsymbol{B})$ keratin 
this temperature range, which turns into a clear exothermic effect at higher temperatures.

Fig.4 (B) shows the thermogram of the regenerated keratin sample. The appearance of shallow endothermic effects on the DTA curve in the temperature range of $20-170{ }^{\circ} \mathrm{C}$, accompanied by a slight loss of mass $(0.88 \%)$, correspond[s] to the release of water residues and plasticization of the matrix. The slight weight loss $(2.23 \%)$ in the temperature range of $170-215{ }^{\circ} \mathrm{C}$ is accompanied by the appearance of a shallow endothermic effect, which corresponds to the initial destructive processes of regenerated keratin.

In the temperature range of $215-282^{\circ} \mathrm{C}$, the regenerated keratin undergoes profound destructive changes caused by denaturation of a-helices of IF and pyrolysis of matrix components. The significant weight loss (14.13\%) and the appearance of a clear endothermic effect on the DTA curve correspond to these processes. In the temperature range of 282 $400{ }^{\circ} \mathrm{C}$, the deep destructive processes in the keratin molecule have been recorded, accompanied by thermal oxidation of [the] degradation residues. This is evidenced by a significant loss of sample mass $(41.49 \%)$ and the appearance of first endo- and then exothermic effects on the DTA curve.

Noteworthy, in comparison with native keratin, regenerated keratin is characterized by a higher thermal stability. The beginning of intense weight loss of regenerated keratin $\left(215^{\circ} \mathrm{C}\right)$, as compared with the native keratin sample $\left(206{ }^{\circ} \mathrm{C}\right)$, is shifted to the region of higher temperatures. In the temperature range of $206-282{ }^{\circ} \mathrm{C}$, regenerated keratin loses weight less intensively (14.13\%), as compared with native keratin $(19.48 \%)$.
An increase in the thermal stability of the regenerated keratin can be explained by a higher relative content of molecules of internal filaments, which, in comparison with the matrix components, are noted by a higher thermal stability. The change in the composition of regenerated keratin predetermines the formation of a more homogeneous structure in it, accompanied by an increase in the amount of the crystalline phase [26].

\section{The study of the films based on regenerated keratin}

Keratins extracted from wool and human hair in aqueous solutions have the ability to selfassembling, forming films. This type of keratin-based biomaterials is successfully used in tissue engineering because they may support and improve cell growth, adhesion, migration, and proliferation, and can be applied for controlled drug deliveries [28].

As can be seen from Fig. 5, the keratinbased film after stabilization in water vapour acquired a gel-like consistency due to the ability of keratin to accumulate moisture.

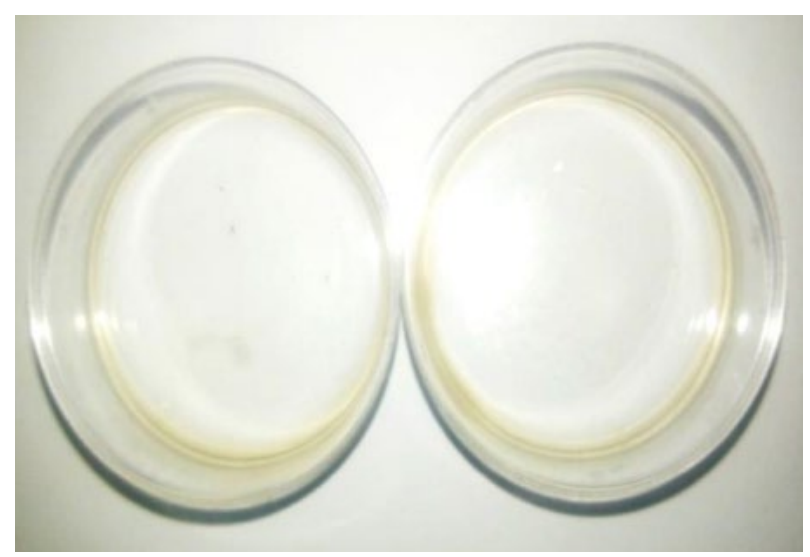

Fig. 5. The film based on regenerated keratin 

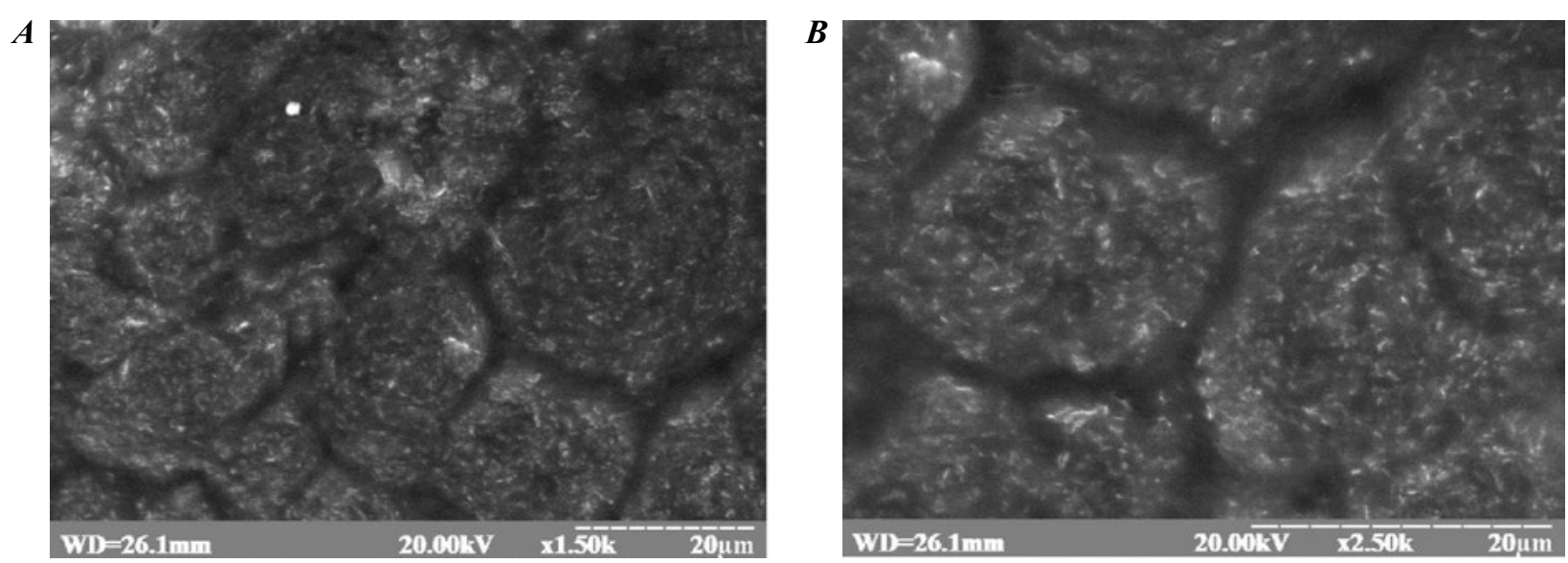

Fig. 6. Electron microscopic image of a film made with $4 \%$ keratin solution with addition of $1 \%$ glycerol; $\times 300$

Fig. 6 shows the surface of the film based on an aqueous solution of keratin, obtained using scanning electron microscopy. As it can be seen from the micrographs, the surface of the film is inhomogeneous, structured, and has a characteristic pattern.

\section{The study of biocompatibility of keratin film}

The protein adsorption analysis is an integral part of material biocompatibility studies [29]. Considering that the implanted material in the body is primarily in contact with blood, our task was to test the ability of the films based on the extracted keratins to form bonds with blood serum proteins.

It is well known that serum albumin quantitatively exceeds all other human blood proteins. It has been established that the adsorption of albumin on the surface inhibits thrombus formation, whereas fibrinogen, in contrast, participates in blood clotting, promotes platelet adhesion and aggregation, and plays an important role in the processes of hemostasis and thrombosis [30]. Therefore, the enhanced adhesion of albumin against fibrinogen is extremely desirable for the successful functionalization of biocompatible coatings.

On the other hand, it is known that the adsorption coefficients of albumin and fibrinogen are significantly related to the nature of the coating, because fibrinogen, being more hydrophobic, is mainly adsorbed on hydrophobic surfaces, whereas albumin being hydrophilic - on hydrophilic surfaces during competitive bonding [31].

Fig. 7 shows the results of electrophoretic separation of proteins adsorbed by the keratinglycerol film. As can be seen from the electrophoregram, the keratin-based film is sufficiently hydrophilic and capable of absorbing a significant amount of albumin, as evidenced by a decrease in the band intensity in the molecular weight range of $60 \mathrm{kDa}$, after 5 and 15 minutes of the incubation in the blood serum. Our results have shown predominant desorption of serum albumin after the incubation of the keratin film in the solution with sodium dodecyl sulfate, which is confirmed by a clear band with a molecular weight of 


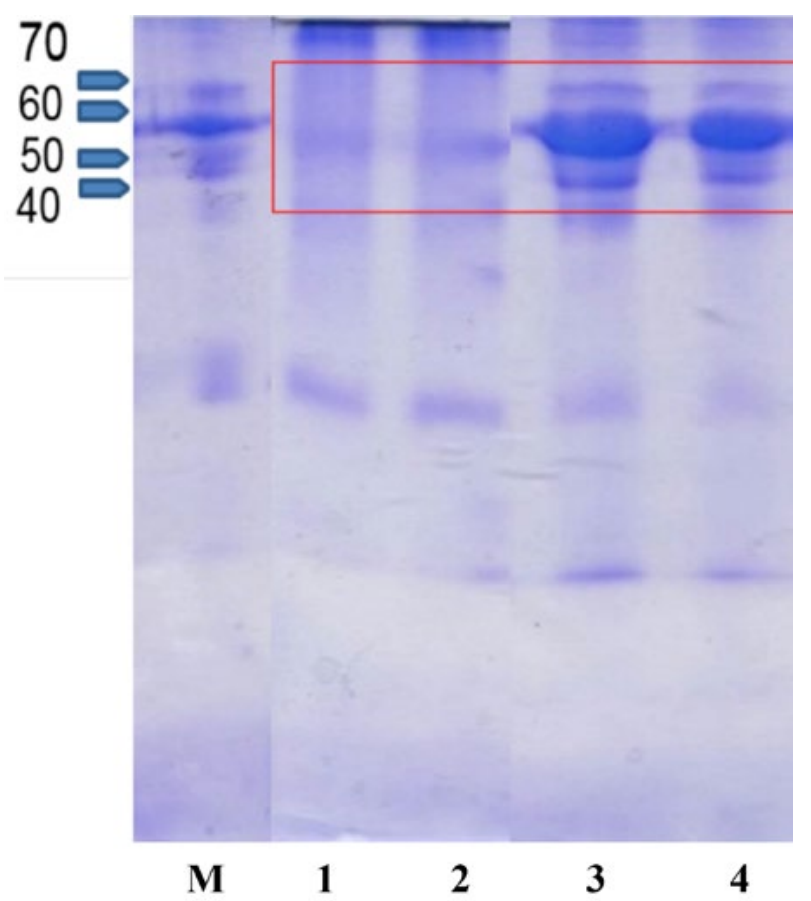

Fig. 7. The electrophoregram of serum proteins after their adsorption/desorption by the keratin film and SDS solution:

$\mathrm{M}$ - molecular weight marker;

1 - serum proteins after incubation with keratin film for 5 min (serum);

2 - serum proteins after incubation with keratin film for 15 min (serum);

3 - serum proteins after incubation with keratin film in SDS solution for $5 \mathrm{~min}$ (SDS solution);

4 - serum proteins after incubation with keratin film in SDS solution for $15 \mathrm{~min}$ (SDS solution).

$60 \mathrm{kDa}$. The detected bands in the range of 60-70 kDa may correspond to the molecular weight of hemoglobin. Additionally, the intensity of protein bands with a molecular weight below $40 \mathrm{kDa}$ was almost the same in all samples. These results indicate that keratin-based films do exhibit a selective ability to adsorb serum albumin.
Therefore, the obtained results indicate that the sulfitolysis method provides a predominant extraction of the keratins with the molecular weight in the range of $45-65 \mathrm{kDa}$. The obtained regenerated keratin is characterized by better thermal stability compared with the native one. The films, based on regenerated keratin with adding of glycerol, have an inhomogeneous relief surface and are characterized by the ability to selectively adsorb albumin from serum. This indicates that our soft method for the extraction of keratins ensures the preservation of their native properties and the ability to form bonds with proteins of living organisms.

\section{Funding}

This research was not funded by any organization.

\section{REFERENCES}

1. Gupta P, Nayak K. Characteristics of protein-based biopolymer and its application. Polym Eng Sci. 2015; 55(3): 485-98.

2. Yang Y, Chen J, Migliaresi C, Motta A. Natural fibrous protein for advanced tissue engineering applications: focusing on silk fibroin and keratin. $A d v$ Exp Med Biol. 2020; 1249:39-49.

3. Makar IA, Gavrylyak V, Sedilo G. Genetical and biochemical aspects of keratin synthesis by hair follicles. Cyt Genet. 2007; 41(1):75-9.

4. Hassan, Mohammad M, Christopher M. Carr. A review of the sustainable methods in imparting shrink resistance to wool fabrics. J Adv Res. 2019; 18:39-60.

5. Shuai $W$, Taraballi $F$, Lay $P$, Kee $W$. Human keratin hydrogels support fibroblast attachment and proliferation in vitro. Cell Tissue Res. 2012; 347:795-802.

6. Pace L, Plate J, Smith T, Van D. The effect of human hair keratin hydrogel on early cellular response to sciatic nerve injury in a rat model. Biomaterials. 2013; 34(24):5907-14. 
7. Aluigi A, Vineis C, Varesano A, Mazzuchetti G, Ferrero $F$, Tonin $C$. Structure and properties of keratin/ PEO blend nanofibres. Eur Polym J. 2008; 44(8):2465-75.

8. Passipieri J, Baker H, Siriwardane M, Ellenburg M, Vadhavkar M, Saul J, Tomblyn S, Burnett L, $C h r i s t ~ G$. Keratin hydrogel enhances in vivo skeletal muscle function in a rat model of volumetric muscle loss. Tissue Eng Part A. 2017; 23(1112):556-71.

9. Borelli M, Joepen N, Reichl S, Finis D, Schoppe M, Geerling $G$, Schrader $S$. Keratin films for ocular surface reconstruction: Evaluation of biocompatibility in an in-vivo model. Biomaterials. 2015; 42:112-120.

10. Bochynska-Czyz M, Redkiewicz P, Kozlowska H, Matalinska J, Konop M, Kosson P. Can keratin scaffolds be used for creating three dimensional cell cultures? Open Med. 2020; 15:249-53.

11. Cheng Z, Chen X, Zhai D, Gao F, Guo T, Li W, Wang $B$. Development of keratin nanoparticles for controlled gastric mucoadhesion and drug release. J Nanobiotechnol. 2018; 16(1):1-13.

12. Gao F, Li W, Deng J, Kan J, Guo T, Wang B, Hao S. Recombinant human hair keratin nanoparticles accelerate dermal wound healing. ACS Appl Mater Interfaces. 2019; 11(20):18681-90.

13. Sierpinski P, Garrett J, Ma J, Apel P, Klorig D, Smith T, Van Dyke M. The use of keratin biomaterials derived from human hair for the promotion of rapid regeneration of peripheral nerves. Biomaterials. 2008; 29(1):118-28.

14. Havryliak V, Mykhaliuk V, Petrina R, Fedorova $O$, Lubenets $V$, Novikov $V$. Adsorbents based on keratin for lead and cadmium removal. Curr Appl Sci Techno. 2020; 20(1):136-43.

15. Sadeghi S, Nourmohammadi J, Ghaee A, Soleimani $N$. Carboxymethyl cellulose-human hair keratin hydrogel with controlled clindamycin release as antibacterial wound dressing. Int J Biol Macromol. 2020; 147:1239-47.

16. Silva N, Vilela C, Marrucho I, Freire S, Neto C, Silvestre J. Protein-based materials: from sources to innovative sustainable materials for biomedical applications. J Mater Chem B. 2014; 2(24):3715-40.
17. Saha S, Arshad M, Zubair M, Ullah A. Keratin as a Biopolymer. In Keratin as a Protein Biopolymer Springer, Cham. 2019; 163-85.

18. Isarankura N, Ayutthaya SIN, Tanpichai S, Wootthikanokkhan J. Keratin extracted from chicken feather waste: extraction, preparation, and structural characterization of the keratin and keratin/ biopolymer films and electrospuns. $J$ Polym Environ. 2015; 23(4):506-16.

19. Bradford $M$. A rapid and sensitive method for the quantitation of microgram quantities of protein utilizing the principle of protein-dyebinding. Anal Biochem. 1976; 72:248-54.

20. Laemmli $U$. Cleavage of structural proteins during the assembly of the head of bacteriophage T4. $\mathrm{Na}$ ture. 1970; 227(5259):680-5.

21. Rocha Plácido Moore G, Maria Martelli S, Gandolfo C, José do Amaral Sobral P, Borges Laurin$d o J$. Influence of the glycerol concentration on some physical properties of feather keratin films. Food Hydrocoll. 2006; 20(7):975-82.

22. Shavandi A, Silva T, Bekhit A, Bekhit AE. Keratin: dissolution, extraction and biomedical application. Biomater Sci. 2017; 5(9): 1699-735.

23. Roy K, Choi W, Yi W, Moon W, Lee R, Han K, Hasebe T. Hemocompatibility of surface-modified, silicon-incorporated, diamond-like carbon films. Acta Biomater. 2009; 5(1):249-56.

24. Rajabi M, Ali A, McConnell M, Cabral J. Keratinous materials: Structures and functions in biomedical applications. Mater Sci Eng: C. 2020; 110:110612. 25. Aziz ME, Jaleeli KA, Ahmad A. FTIR spectroscopic analysis of keratinized tissue-the Hair. Int J Sci Eng Technol. 2017; 6:105-7.

26. de Castro Lima C, Machado L, Velasco M, Du Rosario Matos J. DSC measurements in relation to hair studies. J Therm Anal Calorim. 2018; 132:1429-37.

27. Apostolidou C. Regenerated hoof keratin from 1-ethyl-3methylimidazolium acetate and insights into disulfide ionic liquid interactions from MD Simulation. Chemistry Open. 2020; 9:695-702.

28. McLellan J, Thornhill S, Shelton S, Kumar M. Keratin-based biofilms, hydrogels, and biofibers. Keratin as a Protein Biopolymer. Springer Series on 
Polymer and Composite Materials. Springer, Cham. 2019; 187-200.

29. Rahmati M, Mozafari M. Protein adsorption on polymers. Mater Today Commun. 2018; 17:527-40.

30. Vasilchina H, Popov C, Ulrich S, Ye J, Danneil F, Stüber $M$, Welle A. Wetting behaviour and protein adsorption tests on ultrananocrystalline diamond and amorphous hydrogenated carbon thin films. Nanostructured Materials for Advanced Technological Applications. NATO Science for Peace and Security. Series B: Physics and Biophysics, Dordrecht: Springer. 2009. 547.

31. Popov C, Vasilchina H, Kulisch W, Danneil F, Stüber M, Ulrich S, Welle A, Reithmaier JP. Wettability and protein adsorption on ultrananocrystalline diamond/amorphous carbon composite films. Diam Relat Mater. 2009; 18:895-8.

\section{Характеристика регенерованого кератину та плівки на його основі}

\section{В. В. Гавриляк, В. В. Михалюк, В. В. Кочубей}

Мета. Дослідження характеристик регенерованого кератину, одержаного з волосся людини, створення плівок на основі кератину та вивчення морфології їхньої поверхні й адсорбційної здатності. Методи. Кератини екстрагували сульфітолізом. Структуру регенерованого кератину досліджували методом ІЧ-спектроскопії, термогравіметрії та електрофорезу. Для формування плівок розчин кератину виливали на чашки Петрі.. Їх біосумісність аналізували в адсорбційному тесті шляхом інкубації в сироватці крові людини. Для оцінки морфології поверхні плівок використали сканувальну електронну мікроскопію. Результати. Регенерований кератин представлений переважно протеїнами інтермедіальних філаментів і характеризується кращими термічними властивостями, ніж нативний. Плівки на основі кератину мали яскраво виражену рельєфну структуру. У адсорбційному тесті показано переважну здатність плівок адсорбувати на своїй поверхні альбумін із сироватки крові людини. Висновки.
М'який режим екстракції кератинів методом сульфітолізу забезпечує збереження їхніх нативних властивостей та здатність плівок на основі кератину формувати зв'язки з протеїнами крові.

К л юч о в і с л о в а: біополімери, кератин, сульфітоліз, термогравіметричний аналіз, плівки, адсорбція

\section{Характеристика регенерированного кератина и пленки на его основе}

В. В. Гаврыляк, В. В. Мыхалюк, В. В. Кочубей

Цель. Исследование характеристик регенерированного кератина, полученного из волоса человека методом сульфитолиза, создание на его основе пленок и изучение их поверхности, а также адсорбционной способности. Методы. Кератины экстрагировали сульфитолизом. Структуру регенерированного кератина исследовали методом ИК-спектроскопии, термогравиметрии и электрофореза. Для формирования пленок раствор кератина выливали на чашки Петри. Их биосовместимость анализировали в адсорбционном тесте путем инкубации в сыворотке крови человека. Для оценки морфологии поверхности пленок использовали сканирующую электронную микроскопию. Результаты. Регенерированный кератин представлен преимущественно протеинами интермедиальных филаментов и характеризуется лучшими термическими свойствами, чем исходный. Пленки на основе кератина имели ярко выраженную рельефную структуру. В адсорбционном тесте показано преимущественную способность пленок адсорбировать на своей поверхности альбумин из сыворотки крови человека. Выводы. Мягкая экстракция кератинов методом сульфитолиза обеспечивает сохранение их природных свойств и способность пленок на основе кератина формировать связи с протеинами крови.

Кл юч е в ы е с л о в а: биополимеры, кератин, сульфитолиз, термогравиметрический анализ, пленки, адсорбция.

Received 03.08.2021 